\title{
Reclassification of American Rhizobium leguminosarum Biovar Phaseoli Type I Strains as Rhizobium etli sp. nov.
}

\author{
LORENZO SEGOVIA, ${ }^{1}$ J. PETER W. YOUNG,${ }^{2}$ AND ESPERANZA MARTÍNEZ-ROMERO ${ }^{1 *}$ \\ Departamento de Genética Molecular, Centro de Investigación sobre Fijación de Nitrógeno, Universidad \\ Nacional Autónoma de México, Apartado Postal 565-A, Cuernavaca, Morelos, México, ${ }^{1}$ and \\ Department of Biology, University of York, Heslington, York, Y01 5DD, United Kingdom ${ }^{2}$
}

\begin{abstract}
A new Rhizobium species that nodulates Phaseolus vulgaris $\mathrm{L}_{0}$ is proposed on the basis of a sequence analysis of $16 \mathrm{~S}$ ribosomal DNA. This taxon, Rhizobium etli sp. nov., was previously named Rhizobium leguminosarum biovar phaseoli (type I strains) and is characterized by the capacity to establish an effective symbiosis with bean plants, the reiteration of the nitrogenase structural genes, the organization of the common nodulation genes into two separate transcriptional units bearing $\operatorname{nod} A$ and nodBC, the presence of the polysaccharide inhibition gene, $p s i$, and the $16 \mathrm{~S}$ ribosomal DNA sequence. An analysis of the sequence of a fragment of the 16S rRNA gene shows that this gene is quite different from the gene of $R$. leguminosarum. In addition, all $R$. etli strains have identical sequences. We describe these analyses and discuss additional evidence supporting our proposal.
\end{abstract}

The bacteria of the genus Rhizobium nodulate the roots of leguminous plants. Rhizobium species have been defined primarily on the basis of phenotypic characteristics such as host range, colony morphology, growth on selective media, and certain metabolic attributes. The bacteria that infect peas, clovers, and beans (Phaseolus vulgaris L.) have been clustered in a single species, Rhizobium leguminosarum, which has three biovars $(R$. leguminosarum biovar viciae, $R$. leguminosarum biovar trifolii, and $R$. leguminosarum biovar phaseoli) (11). This subdivision is based mainly on the presence of different symbiotic plasmids coding for distinct nodulation specificities in a uniform chromosomal background. The uniformity of this background has been supported by different types of data; the symbionts of peas, clovers, and beans cannot reliably be distinguished on the basis of phenotypic characteristics (17). Under laboratory conditions, recombination of chromosomal genes among isolates belonging to the different biovars can be obtained easily $(9,13)$; symbiotic plasmids conferring different symbiotic capacities can be transferred among strains isolated from peas, clovers, and beans and remain functional $(7,10$, 14). DNA-DNA hybridization levels are higher among isolates belonging to the three biovars than to isolates belonging to other related species (3); the nucleotide sequences of a $16 \mathrm{~S}$ rDNA fragment from different isolates obtained from peas, clovers, and beans have been found to be identical (6, 25).

This classification has been challenged by several lines of evidence. Heterogeneity in $R$. leguminosarum biovar phaseoli has been identified by a variety of methods, including protein patterns in two-dimensional polyacrylamide gel electrophoresis (21), antibiotic resistance profiles, serological types, DNA-DNA hybridization data (8), plasmid profiles, and exopolysaccharide structures (16). The genetic structures of several $R$. leguminosarum populations have been determined. Young's analysis of three enzymes in a collection of strains belonging to the three biovars of $R$. leguminosarum isolated in English fields showed that there is a considerable amount of sharing of enzyme mobility variants

${ }^{*}$ Corresponding author. among all strains (mostly between isolates of $R$. leguminosarum biovar viciae and $R$. leguminosarum biovar trifolii). However, the strains assigned to $R$. leguminosarum biovar phaseoli were weakly polymorphic (24). In contrast, Piñero et al. established in a study of the genetic structures of a collection of isolates of $R$. leguminosarum biovar phaseoli obtained mostly from Mexico that there is a very high level of heterogeneity in the chromosomal structural genes (19). The genetic distance and genotypic diversity observed were the highest ever reported for any single species of bacterium.

Two different types of strains can be distinguished among isolates from bean nodules. Some strains exhibit the characteristics expected of $R$. leguminosarum biovar phaseoli strains (type I strains) (15), and others have been characterized as a separate species, Rhizobium tropici (formerly type II strains), on the basis of multilocus enzyme electrophoresis data, DNA-DNA hybridization data, ribosomal DNA organization data, data from a sequence analysis of $16 \mathrm{~S}$ ribosomal DNA, and data from an analysis of phenotypic characteristics (16). As part of an analysis of the structure of a nonsymbiotic population of $R$. leguminosarum isolates by multilocus enzyme electrophoresis, we found that bona fide $R$. leguminosarum biovar phaseoli isolates from our collection formed a cluster separate from $R$. leguminosarum biovar viciae and $R$. leguminosarum biovar trifolii (22).

Recently, Eardly et al. analyzed the phylogenetic position of several symbionts of Phaseolus vulgaris L. on the basis of the nucleotide sequence of a fragment of the 16S rRNA gene (6). They found that one Rhizobium sp. type I strain, previously classified as $R$. leguminosarum biovar phaseoli type I, showed a conspicuous number of nucleotide sequence mismatches compared with the $R$. leguminosarum type strain. To avoid confusion below, we follow the suggestion of Eardly et al. and refer to all American isolates obtained from Phaseolus vulgaris as Rhizobium sp. type I. Type I strains were first described by Martínez et al. (15).

We determined the nucleotide sequences of the same region of the 16S rRNA gene from different strains representing the main lineages of Rhizobium sp. type I American strains and from a $R$. leguminosarum biovar viciae Mexican isolate. Our results confirm that these strains form a lineage independent from $R$. leguminosarum. We thus propose a 
new species, Rhizobium etli, which contains one biovar, Rhizobium etli biovar phaseoli.

\section{MATERIALS AND METHODS}

Bacterial strains. The following Rhizobium sp. type I bean isolates were used: CFN 1 (electrophoretic type [ET] 1), CFN $42^{\mathrm{T}}$ ( $\mathrm{T}=$ type strain) (ET 25), Viking 1 (ET 29), CFN 3 (ET 32), and Nitragin 8251 (ET 33). The ETs correspond to those of Piñero et al. (19). In addition, L6, a Rhizobium sp. strain isolated from Pisum sativum in Huitzilac, Morelos, Mexico, was also analyzed.

Growth conditions. Bacteria were maintained in yeastmannitol (YM) medium and in peptone-yeast extract (PY) liquid medium for DNA isolation.

DNA isolation. DNA was purified from cells treated with sodium dodecyl sulfate $(1 \%$ [wt/vol])-Pronase $(50 \mu \mathrm{g} / \mathrm{ml})$, and then subjected to serial extractions with phenol-chloroform (1:1 [vol/vol]) and precipitation with ethanol and $\mathrm{NaCl}$ as described previously (16).

Nucleotide sequence of $16 S$ rRNA genes. The nucleotide sequence of the 16S rRNA genes was determined by directly sequencing double-stranded polymerase chain reaction products with Sequenase 2 (U.S. Biochemical Corp.). A 318-bp fragment of the 16S rRNA gene corresponding to positions 20 to 338 of the Escherichia coli 16S rRNA sequence was amplified with primers Y1 (5'-TGGCTCA GAACGAACGCTGGCGGC-3') and Y2 (5'-CCCACTGCT GCCTCCCGTAGGAGT $\left.-3^{\prime}\right)$ as described previously $(6,25)$. The polymerase chain reaction products were purified by using Magic PCR Preps DNA purification system columns (Promega) and the method suggested by the manufacturer. Direct sequencing with Sequenase was carried out in the presence of $0.5 \%$ ( $\mathrm{vol} / \mathrm{vol}$ ) Nonidet P-40 (a modification of the method of Casanova et al. [2]).

Nucleotide sequence analyses. Nucleotide sequences were aligned by using the PILEUP program of the Genetics Computer Group Sequence Analysis Package (5). J. Felsenstein's PHYLIP 3.4 DNADIST program was used to determine the Jukes-Cantor distances of the aligned sequences (12), and then the unweighted pair group algorithm (UPGMA) was used to determine the phylogenetic relationships (18).

Nucleotide sequence accession numbers. We used the following GenBank (release 72 ) sequences: $R$. leguminosarum 8002, M55494; R. tropici CIAT 899, M55233; Rhizobium sp. strain FL27, M55234; Rhizobium sp. type I strain Olivia 4, M55235; Rhizobium sp. strain Or191, M55236; Agrobacterium tumefaciens, M11223; Rochalimea quintana, M11927; Brucella abortus, X13695; Rhodobacter sphaeroides, X53855; Rhodobacter capsulatus, M34129; Rhodomicrobium vanneilii, M34127; Azorhizobium caulinodans, M55491; Rhodopseudomonas palustris, M55496; Bradyrhizobium sp. strain NZP 2257, M55486; Bradyrhizobium sp. strain BTAi1, M55492; Bradyrhizobium japonicum USDA 110, M55485; Bradyrhizobium japonicum USDA 59, M55489; Bradyrhizobium japonicum USDA 31, M55487; Rhizobium meliloti A, M55242; R. meliloti B, M55243; and Rhizobium fredii, M74163.

\section{RESULTS}

Nucleotide sequence analysis. In order to be able to compare previously published Rhizobium 16S rRNA gene sequences, we amplified a region of the gene from position 20 to position 338 . This region has been extensively used before

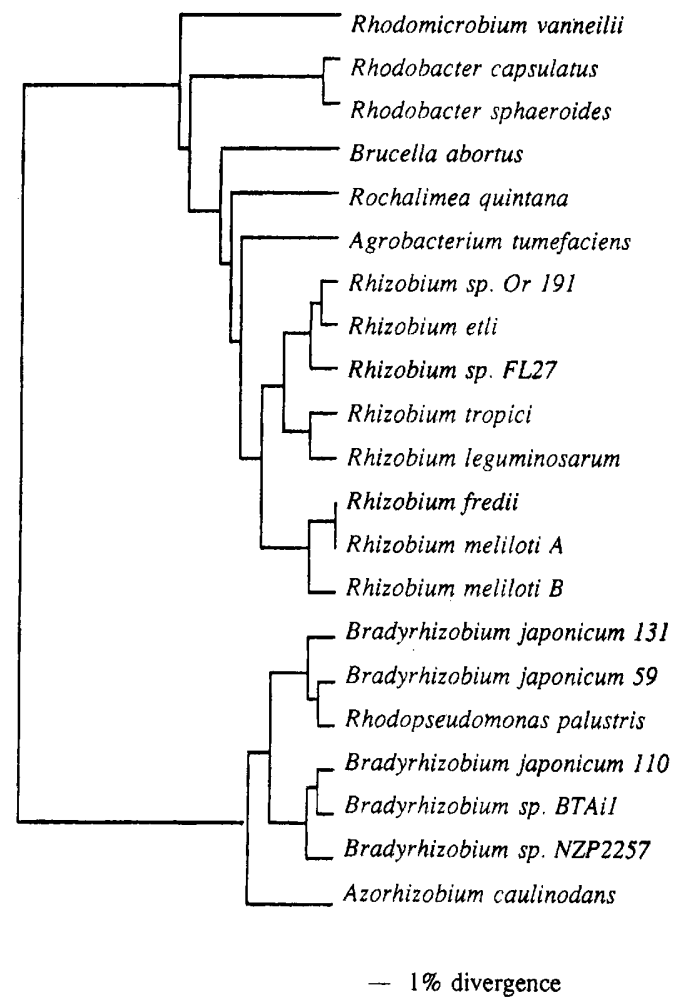

FIG. 1. UPGMA grouping derived from a Jukes-Cantor pairwise distance matrix of the aligned sequences of $16 \mathrm{~S}$ ribosomal DNA fragments from Rhizobium spp. and related bacteria.

to determine taxonomic relationships among rhizobia as it is long and variable enough to permit reliable conclusions $(6$, $25)$. The sequences of this 16S rRNA gene fragment in all strains, including the pea isolate, were identical to the sequence previously reported for Rhizobium sp. type I strain Olivia 4 (6).

Phylogenetic analysis. In order to determine the phylogenetic position of our strains in relation to other Rhizobium and Bradyrhizobium species, we aligned the sequence obtained with known sequences. We then constructed a pairwise Jukes-Cantor distance matrix (12) based on the multiple alignment obtained. Phylogenetic relationships were determined by the UPGMA grouping method (18). The result of this analysis is shown in Fig. 1.

Taxonomic relationships. All Rhizobium sp. type I isolates belong to a lineage independent from the $R$. leguminosarum lineage. They are more closely related to strains isolated from beans than to any other Rhizobium species, as shown in Fig. 1. All species capable of nodulating beans, even those which have a broader host range, are members of a single group separate from $R$. meliloti and $R$. fredii but included in a larger group of fast-growing Rhizobium spp. The slowly growing rhizobia form an independent cluster composed of the different Bradyrhizobium species, including the phototrophic strain BTAi1.

\section{DISCUSSION}

It has been shown that the bacteria able to establish an effective symbiosis with beans form a very heterogeneous group on the basis of a variety of criteria, such as protein patterns in two-dimensional polyacrylamide gel electro- 
phoresis, antibiotic resistance profiles, serological types, DNA-DNA hybridization data, plasmid profiles, and exopolysaccharide structure $(6,15)$. We recently proposed a new species, $R$. tropici, comprising the bean isolates previously called $R$. leguminosarum biovar phaseoli type II (16). One of the main characteristics of these bacteria was the capacity to establish an effective symbiosis with both Phaseolus vulgaris and Leucaena spp. This broad host range distinguished them from the isolates called $R$. leguminosarum biovar phaseoli type $I$, as the latter have been shown to be restricted to beans (15). $R$. leguminosarum biovar viciae and $R$. leguminosarum biovar trifolii isolates, collected in fields in England, were found to share a considerable number of electrophoretic variants of three metabolic enzymes. Nevertheless, $R$. leguminosarum biovar phaseoli isolates were only weakly polymorphic and shared enzyme genotypes with isolates belonging to the other two biovars (24). The genetic cohesiveness of this group was confirmed by the absence of $16 \mathrm{~S}$ rRNA sequence variation (6).

In contrast, the genetic diversity of a collection of Rhizobium sp. type I isolates, mostly from Mexico, was found to be very high (19). The genetic structure of this collection shows that there are among Rhizobium sp. type I strains at least three main lineages separated by a genetic distance greater than 0.6 . In another study of genetic variation it was found that Rhizobium sp. type I isolates belonged to a different cluster than $R$. leguminosarum biovar viciae and $R$. leguminosarum biovar trifolii reference strains. This was also shown by a lower DNA-DNA hybridization level (22). Eardly et al. sequenced a fragment of the 16S rRNA gene from several bean isolates. They found that the sequence from strain Olivia 4, a Rhizobium sp. type I strain, was markedly different from that of $R$. leguminosarum. This indicated that this strain does not belong to $R$. leguminosanum (6).

We determined the sequence of the same fragment of the 16S rRNA gene from Rhizobium sp. type I strains CFN 1, CFN $42^{\mathrm{T}}$, Viking $1, \mathrm{CFN} 3$, and Nitragin 8251 . These strains represent the three main lineages found among Rhizobium sp. type I strains (19). We also included strain L6, an isolate obtained from Pisum sativum in Mexico. In spite of the large genetic distance existing among these strains, we found that all of the sequences are identical to that reported for strain Olivia 4. This indicates that Rhizobium sp. type I isolates belong to a single, cohesive genetic group separate from $R$. leguminosarum.

Phaseolus vulgaris L. originated in the Americas. Cultivated common beans arose from multiple domestications in Mesoamerica and in Andean South America and are thus an introduced crop in Europe. All of the American Rhizobium isolates shown in Fig. 1 share the capacity to establish an effective symbiosis with bean plants although their principal host may be unrelated to beans. Strain Or 191 was originally isolated from field-grown alfalfa (6), strain FL21 was isolated from a bean plant in a field of Leucaena trees (19), and $R$. tropici effectively nodulates Phaseolus vulgaris and Leucaena spp. trees (16). Ostensibly, the only non-American species is $R$. leguminosarum. Although $R$. leguminosarum bv. phaseoli establishes a completely effective symbiosis with bean plants, apparently its only host, this capacity is plasmid borne. It seems that $R$. leguminosarum biovar phaseoli might have arisen from the addition by horizontal transfer of the symbiotic plasmid from a Rhizobium sp. type I strain to a $R$. leguminosarum chromosome. Several lines of evidence support this assumption. The genetic diversity of the Rhizobium sp. type I strains, which also are specific for beans, is much higher than that of $R$. leguminosanum biovar phaseoli strains $(19,24)$. The American origin of the Rhizobium sp. type I strains speaks of a much longer history of coexistence with beans. The $R$. leguminosarum biovar phaseoli strains and the Rhizobium sp. type I strains share a number of genetic characteristics, and most of them seem to be plasmid borne. Genetic analyses have been focused on two strains, $R$. leguminosarum biovar phaseoli 8002 and Rhizobium sp. type I strain CFN $42^{\mathrm{T}}$. The main characteristics distinguishing these strains from strains belonging to other Rhizobium species have been the presence of reiterations of the nitrogenase reductase structural genes (20), the existence of the polysaccharide inhibition gene, psi (1), and the separation of the nod $A$ and nodBC genes $(4,23)$.

The existence of widespread nonsymbiotic Rhizobium sp. type I isolates has been shown previously (22). These nonsymbiotic bacteria share a common chromosome with symbiotic Rhizobium sp. type I strains, as shown by multilocus enzyme electrophoresis, DNA-DNA hybridization levels, ribosomal gene restriction length polymorphisms, and the sequence of a fragment of the 16S rRNA gene (22). When complemented with a Rhizobium sp. type I symbiotic plasmid, they were capable of establishing an effective symbiosis with bean plants. Peas (Pisum sativum L.) originated in the Middle East and are thus an introduced crop in America. Rhizobium sp. type I pea isolates could also conceivably be the product of the horizontal transfer of a $R$. leguminosarum biovar viciae plasmid to a Rhizobium sp. type I chromosomal background.

We therefore propose that Rhizobium sp. type I strains be reclassified as a new species, Rhizobium etli, which includes the nonsymbiotic isolates and at least one biovar, Rhizobium etli biovar phaseoli.

Description of Rhizobium etli sp. nov. Rhizobium etli (et'li. Nahuatl n. etl, Bean; N. L. gen. n. etli, from bean). Aerobic, gram-negative, nonsporeforming flagellated rods that are 0.5 to 1 by 2 to $3 \mu \mathrm{m}$. Colonies are circular, convex, opaque, and usually 2 to $4 \mathrm{~mm}$ in diameter within 2 to 4 days when they are grown on PY agar medium. They are wet and translucent when they are grown on YM medium. These bacteria are unable to grow on Luria broth medium, on PY medium lacking calcium, or in the presence of carbenicillin, spectinomycin, chloramphenicol, or rifampin. They are able to grow on minimal medium containing malate as a carbon source, but not with arginine, hypoxanthine, or sorbitol as a carbon source. The maximum growth temperature is $35^{\circ} \mathrm{C}$. All strains are nalidixic acid resistant. They are distinguished from other species at the molecular level by the results of whole-DNA hybridization tests, their multilocus enzyme electrophoresis profiles, and their ribosomal gene sequences.

$R$. etli biovar phaseoli strains nodulate and fix nitrogen on Phaseolus vulgaris L. exclusively. They are distinguished from other species at the molecular level by the presence of nitrogenase reductase gene reiterations and the separation of the $\operatorname{nod} A$ and $\operatorname{nod} B C$ genes, which form two separate transcriptional units.

Well-studied $R$. etli biovar phaseoli CFN 42 is designated the type strain; it has the characteristics described above for $R$. etli sp. nov. This strain belongs to $R$. etli biovar phaseoli because it is capable of nodulating beans effectively and has the molecular traits described above.

\section{ACKNOWLEDGMENTS}

This work was partially supported by UNAM-DGAPA grant IN203691. 
We acknowledge M. A. Rogel for help and G. Laquerre and N. Amarger for communicating their results.

\section{ADDENDUM IN PROOF}

Additional DNA-DNA hybridization carried out by G. Laquerre and N. Amarger (Microbiologie des Sols, Institut National de la Recherche Scientifique BV 1540, F-21034 Dijon Cedex, France) gave an average of $45 \%$ homology between $R$. leguminosarum bv. viciae 10004 and $R$. etli CFN 42 .

\section{REFERENCES}

1. Borthakur, D., J. A. Downie, A. W. B. Johnston, and J. W. Lamb. 1985. psi, a plasmid-linked Rhizobium phaseoli gene that inhibits exopolysaccharide production and which is required for symbiotic nitrogen fixation. Mol. Gen. Genet. 200:278-282.

2. Casanova, J. L., C. Pannetier, C. Jaulin, and P. Kourilsky. 1990. Optimal conditions for directly sequencing double stranded PCR products with Sequenase. Nucleic Acids Res. 18:4028.

3. Crow, V. L., B. D. W. Jarvis, and R. M. Greenwood. 1981. Deoxyribonucleic acid homologies among acid-producing $R h i$ zobium. Int. J. Syt. Bacteriol. 31:152-172.

4. Davies, E. O., and A. W. B. Johnston. 1990. Regulatory functions of the three nodD genes of Rhizobium leguminosarum bv. phaseoli. Mol. Microbiol. 4:921-932.

5. Devereux, J., P. Haeberly, and O. Smithies. 1984. A comprehensive set of sequence analysis programs for the VAX. Nucleic Acids Res. 12:387-395.

6. Eardly, B. D., J. P. W. Young, and R. K. Selander. 1992. Phylogenetic position of Rhizobium sp. strain Or 191, a symbiont of both Medicago sativa and Phaseolus vulgaris, based on partial sequences of the 16S rRNA and nifH genes. Appl. Environ. Microbiol. 58:1809-1815.

7. Hooykaas, P. J. J., A. A. N. van Brussel, H. den Dulk-Ras, G. M. S. van Slotgeren, and R. A. Schilperoort. 1981. Sym plasmid of Rhizobium trifolii expressed in different rhizobial species and in Agrobacterium tumefaciens. Nature (London) 291:351-353.

8. Jarvis, B. D. W., A. G. Dick, and R. M. Greenwood. 1980. Deoxyribonucleic acid homology among strains of Rhizobium trifolii and related species. Int. J. Syst. Bacteriol. 30:42-52.

9. Johnston, A. W. B., and J. E. Beringer. 1977. Chromosomal recombination between Rhizobium species. Nature (London) 267:611-613.

10. Johnston, A. W. B., J. L. Beynon, A. V. Buchanan-Wollaston, S. M. Setchel, P. R. Hirsh, and J. E. Beringer. 1978. High frequency transfer of nodulation ability between strains and species of Rhizobium. Nature (London) 276:634-636.

11. Jordan, D. C. 1984 . Family III. Rhizobiaceae Conn 1938, 321 ${ }^{\mathrm{AL}}$, p. 234-254. In N. R. Krieg and J. G. Holt (ed.), Bergey's manual of systematic bacteriology, vol. 1. Williams \& Wilkins, Baltimore.

12. Jukes, T. H., and C. R. Cantor. 1969. Evolution of protein molecules, p. 21-132. In H. N. Munro (ed.), Mammalian protein metabolism. Academic Press, New York.

13. Kondorosi, A., E. Vincze, A. W. B. Johnston, and J. E. Beringer. 1980. A comparison of three Rhizobium linkage maps. Mol. Gen. Genet. 178:403-408.

14. Lamb, J. W., G. Hombrecher, and A. W. B. Johnston. 1982. Plasmid-determined nodulation and nitrogen fixation abilities in Rhizobium phaseoli. Mol. Gen. Genet. 186:449-452.

15. Martínez, E., M. Flores, S. Brom, D. Romero, G. Dávila, and R. Palacios. 1988. Rhizobium phaseoli: a molecular genetics view. Plant Soil 108:179-184.

16. Martínez-Romero, E., L. Segovia, F. Martins Mercante, A. A. Franco, P. Graham, and M. A. Pardo. 1991. Rhizobium tropici, a novel species nodulating Phaseolus vulgaris $\mathrm{L}$. beans and Leucaena sp. trees. Int. J. Syst. Bacteriol. 41:417-426.

17. Moffett, M. L., and R. R. Colwell. 1968. Adansonian analysis of the Rhizobiaceae. J. Gen. Microbiol. 51:245-266.

18. Nei, M., J. C. Stephens, and N. Saitou. 1985. Methods for computing the standard errors of branching points in an evolutionary tree and their application to molecular data from humans and apes. Mol. Biol. Evol. 2:66-85.

19. Piñero, D., E. Martínez, and R. K. Selander. 1988. Genetic diversity and relationships among isolates of Rhizobium leguminosarum biovar phaseoli. Appl. Environ. Microbiol. 54:28252832.

20. Quinto, C., H. de la Vega, M. Flores, L. Fernández, T. Ballado, G. Soberón, and R. Palacios. 1982. Reiteration of nitrogen fixation gene sequences in Rhizobium phaseoli. Nature (London) 299:724-726.

21. Roberts, G. P., W. T. Leps, L. E. Silver, and W. J. Brill. 1980. Use of two-dimensional polyacrylamide gel electrophoresis to identify and classify Rhizobium strains. Appl. Environ. Microbiol. 39:414-422.

22. Segovia, L., D. Piñero, R. Palacios, and E. Martínez-Romero. 1991. Genetic structure of a soil population of nonsymbiotic Rhizobium leguminosarum. Appl. Environ. Microbiol. 57:426433.

23. Vázquez, M., A. Dávalos, A. de las Peñas, F. Sánchez, and C. Quinto. 1991. Novel organization of the common nodulation genes in Rhizobium leguminosarum bv. phaseoli strains. J. Bacteriol. 173:1250-1258.

24. Young, J. P. W. 1985. Rhizobium population genetics: enzyme polymorphism in isolates from peas, clover, beans, and lucerne grown at the same site. J. Gen. Microbiol. 131:2399-2408.

25. Young, J. P. W., H. L. Downer, and B. D. Eardly. 1991. Phylogeny of the phototrophic Rhizobium strain BTAil by polymerase chain reaction-based sequencing of a 16S rRNA gene segment. J. Bacteriol. 173:2271-2277. 